University of Nebraska - Lincoln

DigitalCommons@University of Nebraska - Lincoln

June 2001

DESCRIPTIONS OF THE LARVAE OF HOPLOPYGA SINGULARIS (GORY AND PERCHERON) AND HOLOGYMNETIS CINEREA (GORY AND PERCHERON) WITH A REVISED KEY TO THE LARVAE OF NEW WORLD GYMNETINI (COLEOPTERA: SCARABAEIDAE: CETONIINAE)

\author{
Estefanía Micó \\ Universidad de Alicante, Spain, e.mico@carn.ua.es \\ W. Eugene Hall \\ University of Nebraska State Museum, whall@unlserve.unl.edu \\ Brett C. Ratcliffe \\ University of Nebraska-Lincoln, bratcliffe1@unl.edu
}

Follow this and additional works at: https://digitalcommons.unl.edu/entomologypapers

Part of the Entomology Commons

Micó, Estefanía ; Hall, W. Eugene; and Ratcliffe, Brett C., "DESCRIPTIONS OF THE LARVAE OF HOPLOPYGA SINGULARIS (GORY AND PERCHERON) AND HOLOGYMNETIS CINEREA (GORY AND PERCHERON) WITH A REVISED KEY TO THE LARVAE OF NEW WORLD GYMNETINI (COLEOPTERA: SCARABAEIDAE: CETONIINAE)" (2001). Papers in Entomology. 38.

https://digitalcommons.unl.edu/entomologypapers/38

This Article is brought to you for free and open access by the Museum, University of Nebraska State at DigitalCommons@University of Nebraska - Lincoln. It has been accepted for inclusion in Papers in Entomology by an authorized administrator of DigitalCommons@University of Nebraska - Lincoln. 


\title{
DESCRIPTIONS OF THE LARVAE OF HoplopyGa SINGULARIS (GORY AND Percheron) And Hologymatis cinerea (Gory and Percheron) With a Revised Key to THE LaRVAe OF NeW World GyMnetini (Coleoptera: Scarabaeidae: Cetoninae)
}

\author{
Estefanía Micó \\ Departamento de Ciencias Ambientales y Recursos Naturales \\ Universidad de Alicante, Apartado 99 \\ E-03080 Alicante, SPAIN \\ e.mico@carn.ua.es \\ W. Eugene Hall \\ Systematics Research Collections \\ W436 Nebraska Hall \\ University of Nebraska State Museum \\ Lincoln, NE 68588-0514, U.S.A. \\ whall@unlserve.unl.edu \\ AND \\ BRETt C. RATCLIFFE \\ Systematics Research Collections \\ W436 Nebraska Hall \\ University of Nebraska State Museum \\ Lincoln, NE 68588-0514, U.S.A. \\ bratcliffe1@unl.edu
}

\begin{abstract}
The larvae of two cetoniine scarab beetles, Hoplopyga singularis (Gory and Percheron) from Brazil and Hologymnetis cinerea (Gory and Percheron) from Mexico, are described. The latter is the first description of a larva in this genus. Both of these species are included in a revised key to the larvae of New World Gymnetini (Scarabaeidae: Cetoniinae), which now includes ten species in eight genera.

\section{Resumen}

Se describen las larvas de dos cetoninos, Hoplopyga singularis (Gory and Percheron) de Brasil y de Hologymnetis cinerea (Gory and Percheron) de México, siendo esta última, la primera descripción larvaria para el género Hologymnetis. Se aporta una nueva clave de identificación para las especies de Gymnetini (Scarabaeidae: Cetoniinae) del Nuevo Mundo, incluyendo un total de diez especies y ocho géneros.
\end{abstract}

Morón and Ratcliffe (1984) provided a key to the larvae of the seven thenknown species of New World Gymnetini (Scarabaeidae: Cetoniinae). Although this group of beetles includes over 150 New World species, only one new larval description (Vanin and Costa 1984) has been published in the last 15 years. There are several reasons for the lack of research on larval gymnetines, but principal among them is the difficulty in rearing larvae (time, proper food 
Table 1. Described Larvae of New World Gymnetini (Scarabaeidae: Cetoniinae).

\begin{tabular}{ll}
\hline \multicolumn{1}{c}{ Species } & \multicolumn{1}{c}{ Publication } \\
\hline $\begin{array}{l}\text { Argyripa lansbergei (Sallé) } \\
\text { Blaesia atra Burmeister }\end{array}$ & Morón and Ratcliffe 1984 \\
$\begin{array}{l}\text { Cotinis mutabilis } \text { (Gory and Percheron) } \\
\text { (published as C. texana Casey) }\end{array}$ & Monné 1969 \\
Cotinis nitida (L.) & Ritcher 1966 \\
Gymnetina cretacea (LeConte) (in key only) & Ritcher 1966 1966 \\
Gymnetis flavomarginata sallei Schaum & Ritcher 1966 \\
Hologymnetis cinerea (Gory and Percheron) & this publication \\
Hoplopyga brasiliensis (Gory and Percheron) & Vanin and Costa 1984 \\
Hoplopyga singularis (Gory and Percheron) & this publication \\
Marmarina tigrina (Gory and Percheron) & Monné 1969 \\
\hline
\end{tabular}

and habitat, climate), identifying unassociated field-collected larvae with adults, and unfamiliarity with larval structures and the substantially different vocabulary referring to those structures. Many opportunities await the entomologist willing to advance our knowledge of larval form and function. We supplement the knowledge of larval gymnetines here with the first descriptions of two species and one genus. See Table 1 for a complete listing of gymnetine larval descriptions.

The larvae of gymnetines feed on vegetable and organic debris. Bruch (1919) observed the following gymnetine adults in ant nests of Acromyrmex lundi Guerin in Argentina: Heterocotinis semiopaca (Moser), Corvicoana reticulata (Kirby), Gymnetis chalcipes (Gory and Percheron), and Marmarina tigrina (Gory and Percheron). We report here the presence of adults and larvae of Hoplopyga singularis (Gory and Percheron) in termite nests in Brazil. Luederwaldt (1911) observed larvae of H. albiventris (Gory and Percheron) living inside the termite nests of Cornitermes species in Brazil feeding directly on the organic walls of the nest; larvae lived in the nest while the adults abandoned the nest soon after emergence. Adults fed on flowers and the sap of Baccharis species. Other species of adult Hoplopyga have been taken on rotting fruit and resting on vegetation. Ratcliffe and Deloya (1992) reported species of Hologymnetis feeding on rotting fruit, flowers, and the sap of several trees and shrubs (Baccharis and Acacia species).

The larvae of Cetoniinae may be recognized by the following combination of characters (after Ritcher 1966): Labrum symmetrical. Mandibles each with a ventral, oval, stridulatory area consisting of transverse ridges. Maxillary stridulatory teeth with anteriorly directed points. Epipharynx with a single nesium (sclerotized plate absent). Plegmata and proplegmata absent. Haptomerum of epipharynx usually with a conspicuous, transverse, curved row of stout setae. Lacinia of each maxilla with a single distal uncus or with two, unequally-sized unci that are fused at their bases. Abdominal segments IX and X fused dorsally in some genera. Palidia present or absent. Anal slit transverse, often curved.

There is, at present, no key to tribes of larval Cetoniinae because not enough larvae have been described to ascertain any patterns of character distribution. Consequently, we cannot at this time distinguish the larvae of the tribe Gymnetini from the larvae of any other tribes of cetoniines. 


\section{Key to the Known Third Stage Larvae of New World Gymnetini}

(Modified from Morón and Ratcliffe 1984)

1. Palidia present

1'. Palidia absent _____ Gymnetina cretacea (LeConte)

2. Raster with each palidium consisting of 2 or more irregular rows of pali. Last antennal segment with 3-7 dorsal sensory spots. Haptomeral process absent

$2^{\prime}$. Palidia monostichous. Other characters not as above _. 5

3. Tarsungulus with 7 setae (Fig. 19). Maxillary stridulatory area with 5 irregularly spaced, close-set, low teeth (Fig. 25). Last segment of antenna with 3 ventral sensory spots (Fig. 20b)

Hologymnetis cinerea (Gory and Percheron)

$3^{\prime}$. Tarsungulus with 10-12 setae. Maxillary stridulatory area with 7-9 regularly spaced, high teeth. Last segment of antenna with 5-13 ventral sensory spots

4 (Cotinis)

4. Raster with inner row of each palidium set with pali only slightly larger than those in outer row C. nitida (L.)

$4^{\prime}$. Raster with inner row of each palidium having 7-10 pali much stouter and larger than other pali

5. Transverse haptomeral process present

C. mutabilis (Gory and Percheron)

5'. Transverse haptomeral process absent

6. Dorsum of abdominal segment VII with 3 annulets. Last antennal segment with 10-15 dorsal sensory spots Argyripa lansbergei (Sallé)

$6^{\prime}$. Dorsum of abdominal segment VII with 2 annulets. Last antennal segment with 3 dorsal sensory spots 7 (Hoplopyga)

7. Right mandible with 2 scissorial teeth. Haptomeral region with cone-like haptomeral process over a transversal row of 8-11 heli

H. singularis (Gory and Percheron)

7 '. Right mandible with 3 scissorial teeth. Haptomeral region with a transversal row of 17-19 heli, cone process absent

H. brasiliensis (Gory and Percheron)

8. Maxillary stridulatory area with a row of 3-5 teeth. Tarsungulus bearing $10-12$ setae Gymnetis flavomarginata sallei Schaum

$8^{\prime}$. Maxillary stridulatory area with 6 or more teeth. Tarsungulus with less than 10 setae

9. Maxillary stridulatory area with row of 7 teeth. Tarsungulus bearing 6-7 setae Blaesia atra Burmeister

$9^{\prime}$. Maxillary stridulatory area with a row of 9 teeth. Tarsungulus bearing 56 setae Marmarina tigrina (Gory and Percheron)

\section{Larvae of Hoplopyga Thomson}

The larval description presented here for Hoplopyga singularis (Gory and Percheron) from Brazil is the second for the genus. Hoplopyga brasiliensis (Gory and Percheron), also from Brazil, was described by Vanin and Costa (1984) and reprinted in Costa et al. (1988). Hoplopyga larvae are most similar morphologically to the larvae of Argyripa species, but they are easily distinguished. In species of Hoplopyga, the last antennal segment has three dorsal sensory spots, and the dorsum of abdominal segment VII has two annulets. In species of Argyripa there are 10-15 dorsal sensory spots and the dorsum of abdominal segment VII has three annulets. 
The genus Hoplopyga contains about 20 species distributed from Mexico to Argentina, and it is currently being revised by Ratcliffe. Adults of Hoplopyga have been collected from rotting fruits (especially plantains and bananas), resting on foliage, and in termite nests. Larvae of Hoplopyga are known to feed on rotting wood and other organic debris. Hoplopyga singularis is found in southern Brazil and northern Argentina.

\section{Hoplopyga singularis (Gory and Percheron)}

Third Instar Larva (Figs. 1, 3-15). This description is based on four third instar larvae reared from 12 second instar larvae collected from a termite nest. Locality data: "Itirapinas, São Paulo, Brazil, 21-VII-1996, E. Micó leg". Seven of these larvae were reared to adults to ensure species identification. A badly damaged pupa was also obtained, but it is too incomplete for description. Specimens are deposited at the Collection of Entomology of the University of Alicante, Spain (CEUA) and at the University of Nebraska State Museum (UNSM).

Description. Maximum width of head capsule $3.52 \mathrm{~mm}$. Cranium (Fig. 4). Color light yellowish brown. Frons sparsely punctate, with single posterior frontal seta and single anterior angle seta. Dorsoepicranium with 3-4 small setae in a line diverging from center-base of head. Clypeus. Shape subtrapezoidal with posterior clypeal setae and 2 exterior clypeal setae at postclypeus on each side. Preclypeus weakly sclerotized, without setae. Labrum trilobed, clithra present. Epipharynx (Fig. 10). Plegmata absent. Corypha with 4 long, stout, setae. Haptomeral region with cone-like process bearing 5-6 sensillae at apex and 2 sensillae on each side; behind process a curved row of 8-11 heli in a transverse row, 7-10 stout spine-like setae behind row. Acanthoparia with 8 short setae. Chaetoparia with 57-61 setae on each side. Dexiotorma well developed, with poorly developed pternotorma. Laeotorma shorter and with pternotorma present. Nesia with sensorial cone. Haptolachus with 4 sensilla below sensorial cone. Mandibles. Left mandible (Figs. 11a, 13b) with 1 scissorial tooth anterior to scissorial notch and 2 scissorial teeth posterior to notch. Stridulatory area elongate-oval, length over 2 times its width. Lateral edge with 11-12 setae. Dorsal surface in apical half with 2 setae. Molar area bilobed, dorsomolar area with 2 setae. Basomedian angle with brustia consisting of 7 setae. Right mandible (Figs. 11b, 13a) with 2 scissorial teeth, stridulatory area similar in shape to that of left mandible. Lateral edge with 11-12 setae also. Dorsal surface in apical half with 2 setae. Molar area trilobed, dorsomolar area with 3-4 dorsomolar setae. Calyx present. Maxilla. Galea and lacinia fused (Fig. 12), forming mala. Mala with large uncus at apex and 2 subterminal unci fused at bases and unequal in size; surface with 4 indistinct rows of setae. Cardo with 3-10 setae. Stridulatory area (Fig. 14) with row of 4-5 curved, acute teeth and a distal, truncate process. Labium. Dorsal surface (Fig. 9) with well developed truncate process. Hypopharyngeal sclerome with group of 8 setae on left side; both lateral lobes with 7-13 setae arranged in 2-3 rows. Glossa with transversal row of 11-13 setae at base, 8-9 small setae and 2 larger setae at middle, and 1 or 2 larger setae at each end of row, a group of 18-19 setae arranged in 2 or 3 rows, and a pair of sensilla on each side. Antennae. Surface (Fig. 8) with 3 dorsal and 3 ventral sensory spots on last segment. First segment of antenna as long as following 2 segments together. Thorax. Thoracic spiracles (Fig. 6) with C-shaped respiratory plate, size $0.32-0.36 \mathrm{~mm}$ high and $0.22-0.24 \mathrm{~mm}$ wide; plate with 16 holes across 


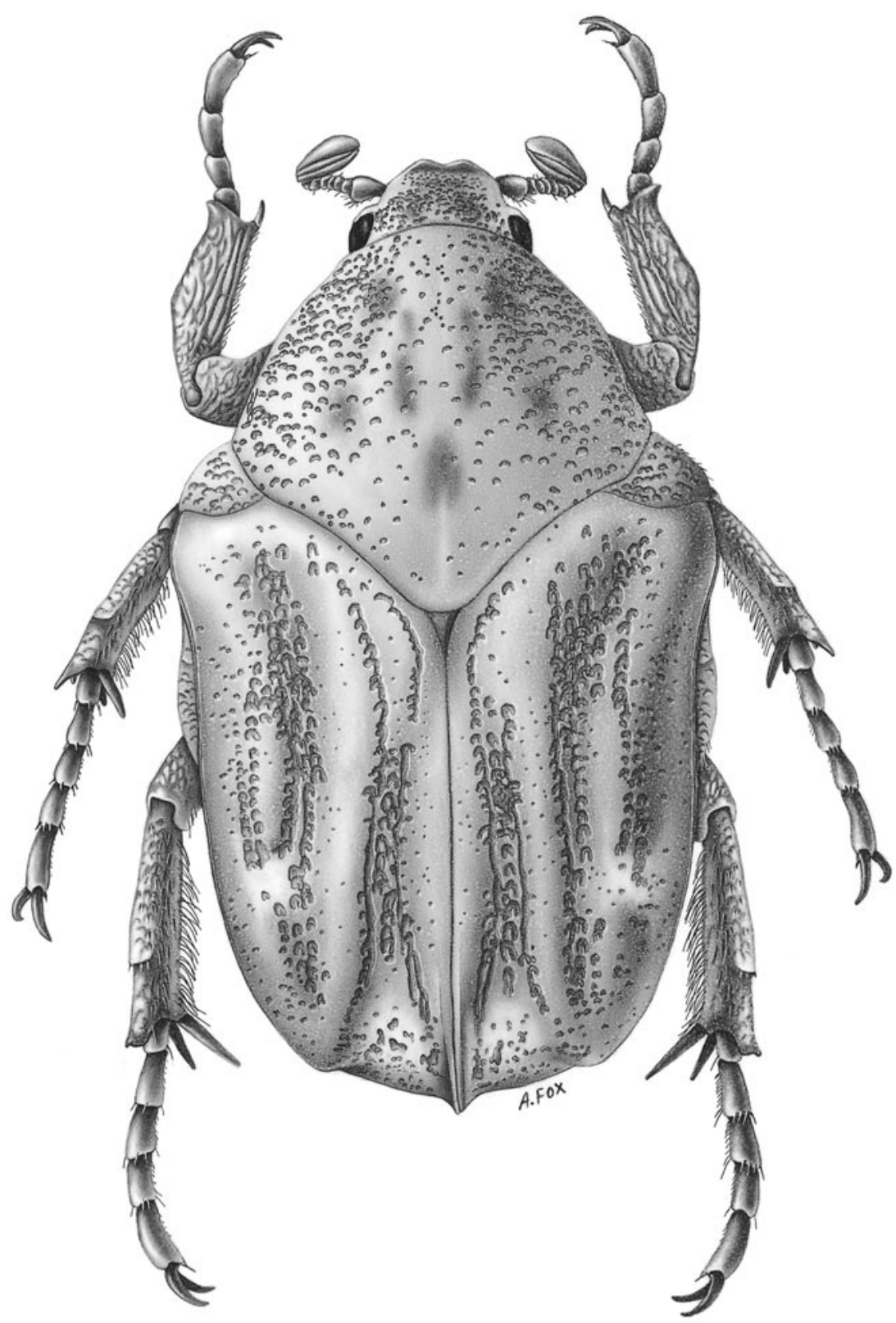

Fig. 1. Dorsal habitus of adult Hoplopyga singularis (Gory and Percheron). 


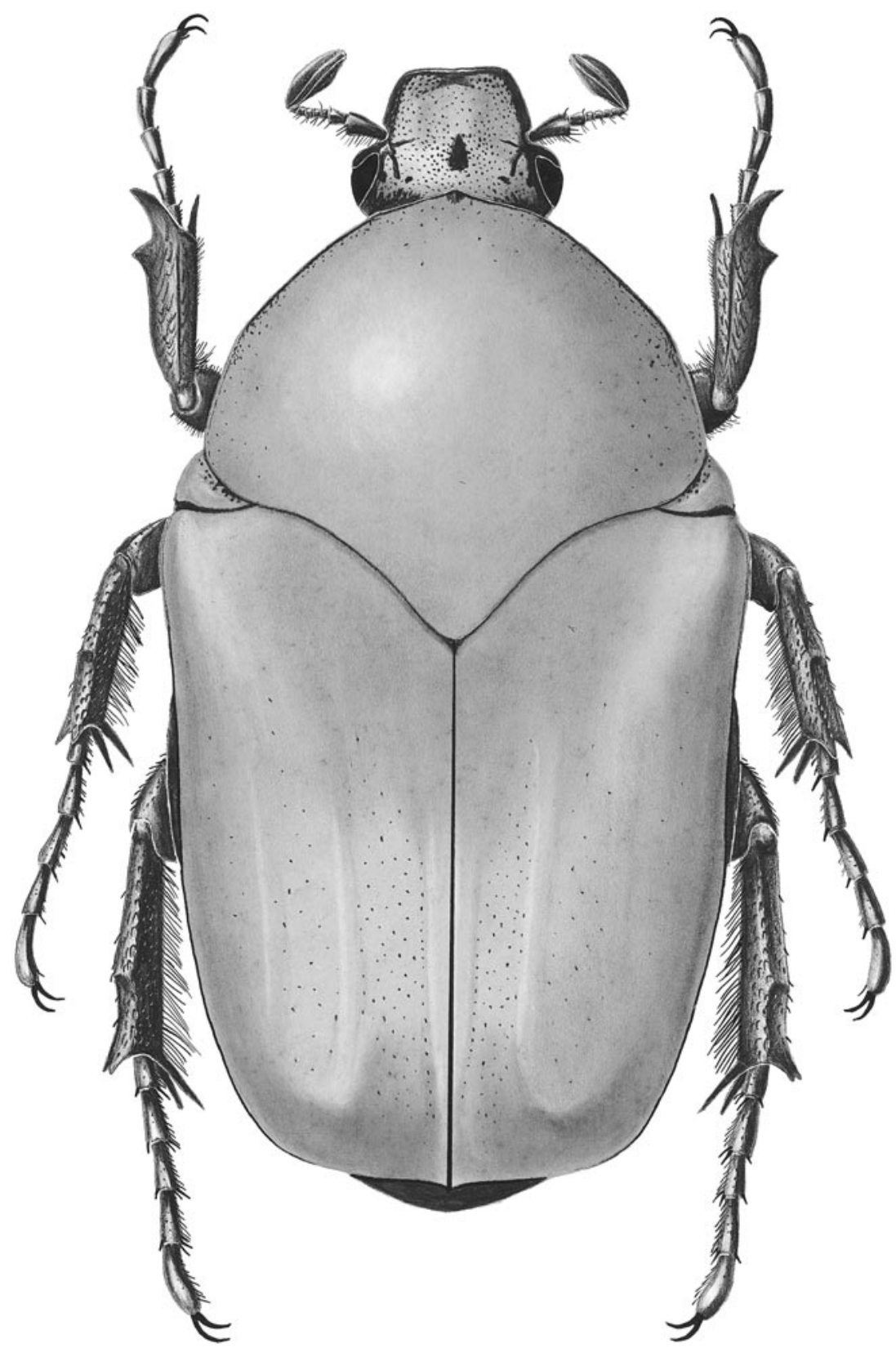

Fig. 2. Dorsal habitus of adult Hologymnetis cinerea (Gory and Percheron). 

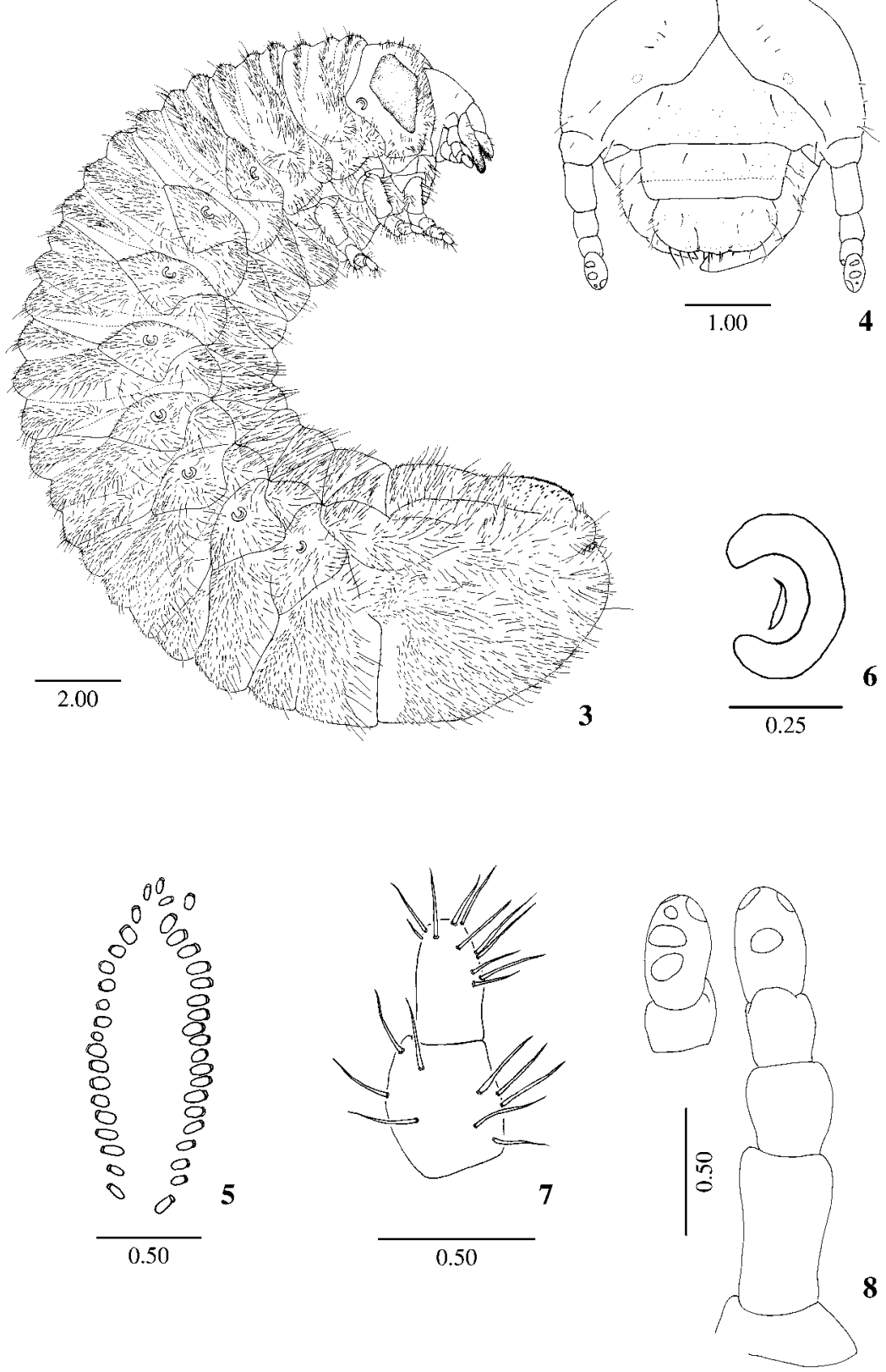

Figs. 3-8. Hoplopyga singularis, third instar larva. 3) Lateral view of larva; 4) Frontal view of head; 5) Palidia; 6) Thoracic spiracle; 7) Tarsungulus of anterior leg; 8) Dorsal view of antenna and ventral view of apical segment showing sensory spots. 

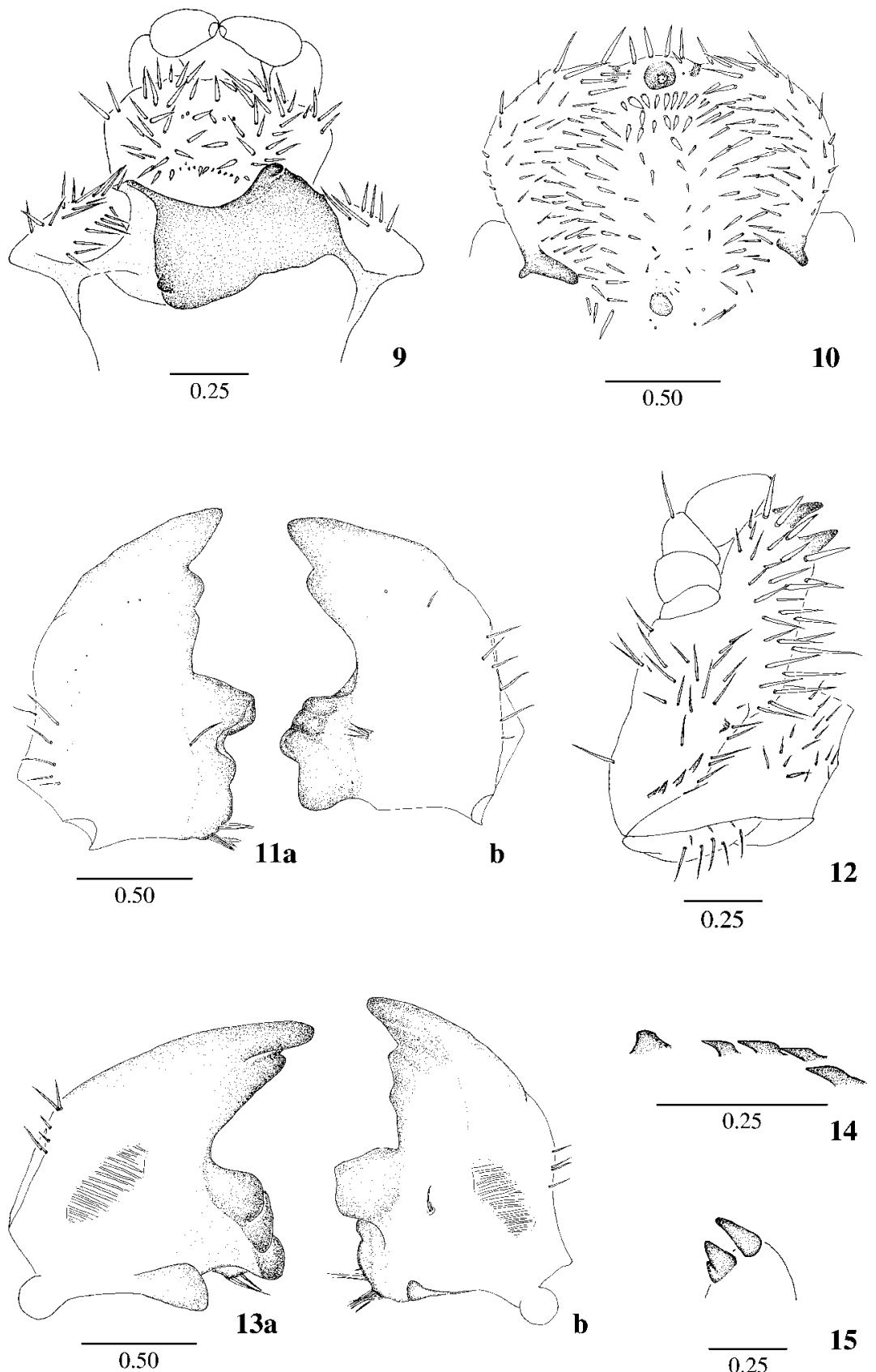

Figs. 9-15. Hoplopyga singularis, third-instar larva. 9) Dorsal view of hypopharynx; 10) Epipharynx; 11) Dorsal view of (a) left and (b) right mandible; 12) Dorsal view of maxilla; 13) Ventral view of (a) right and (b) left mandible; 14) Stridulatory area of maxilla; 15) Apex of right mala showing unci. 
diameter at middle, holes irregularly suboval. Abdomen. Spiracles of abdominal segments I-VII similar in size, those of abdominal segment VIII slightly smaller. Scutum of abdominal segments I-VIII (Fig. 3) usually with more than 10 rows of short setae, each posterior row with several long setae. Segments IX and X fused, covered with short setae and some sparse, long setae. Spiracular area of abdominal segments I-VIII with 60-90 short and medium sized setae; pleural lobes of same segments with 30-50 setae. Raster with pair of palidia (Fig. 5), each consisting of a row of 18-25 pali, rows joined anteriorly. Septula oval, length 2.5 times its width. Tegilla composed of numerous short, thick setae and some cylindrical, long setae. Lower anal lip with sparse short setae and 1 or 2 transverse rows of cylindrical, long setae. Legs. Tarsungulus (Fig. 7) cylindrical, apex rounded and bearing 12-15 setae.

\section{Larvae of Hologymnetis Martínez}

The larval description of Hologymnetis cinerea (Gory and Percheron) that follows is the first for the genus. Larvae of Hologymnetis (to the extent known based upon only one species) are most similar morphologically to those of Cotinis species. Larvae of Hologymnetis have the tarsungulus with seven setae, a maxillary stridulatory area with five irregularly spaced, low teeth, and the last segment of the antenna with three ventral sensory spots. Larvae of Cotinis have a tarsungulus with 10-12 setae, a maxillary stridulatory area with 7-9 regularly spaced, high teeth, and the last segment of the antenna with 5-13 ventral sensory spots.

The genus Hologymnetis consists of seven species that are found from the southwestern United States to southern Brazil; the genus was revised by Ratcliffe and Deloya (1992). Adults of Hologymnetis species have been found in the detritus piles of leaf cutter ants (Atta sp.) and are known to feed on rotting fruit, flowers, and the sap of several trees and shrubs (Baccharis and Acacia species). Like other gymnetines, the larvae feed in compost and rotting wood. It is not known whether the adults are obligate myrmecophiles or whether the larvae are also found in ant nests.

\section{Hologymnetis cinerea (Gory and Percheron)}

Third Instar Larva (Figs. 2, 16-26). This description is based on two thirdinstar larvae associated with an adult recovered from the nest debris piles of Atta mexicana (Smith) (Hymenoptera: Formicidae) under hecho cactus, $\mathrm{Pa}$ chycereus pecten-aboriginum Britton and Rose (Cactaceae). Locality data: "Mexico: Sonora, 1.0 miles by road to Microondas la Luna, NW jet with Mex. hwy 162 (Alamos Rd.), $440 \mathrm{~m}$ elevation, lat. $27^{\circ} 04^{\prime} \mathrm{N}$, long. $109^{\circ} 01^{\prime} \mathrm{W}$, tropical deciduous forest, X-19-1996, P. Holm". Specimens are deposited at the University of Nebraska State Museum (UNSM).

Description. Maximum width of head capsule $4.50 \mathrm{~mm}$. Cranium (Fig. 16). Color reddish brown. Frons with shallow reticulations, surface moderately punctate, with single posterior frontal seta and single anterior angle seta. Dorsoepicranium with 5-6 small setae in a line diverging from center-base of head. Clypeus. Shape subtrapezoidal with 2 posterior clypeal setae and 2 exterior clypeal setae at post clypeus on each side. Preclypeus weakly sclerotized, setae absent. Labrum trilobed, clithra present. Epipharynx (Fig. 22). Plegmata absent. Corypha with 4 long, stout setae. Haptomeral region lacking process and with curved row of 10-12 heli in transverse row, 10-13 stout spine-like setae irregularly placed behind curved row. Acanthoparia with 6 short setae. Chae- 

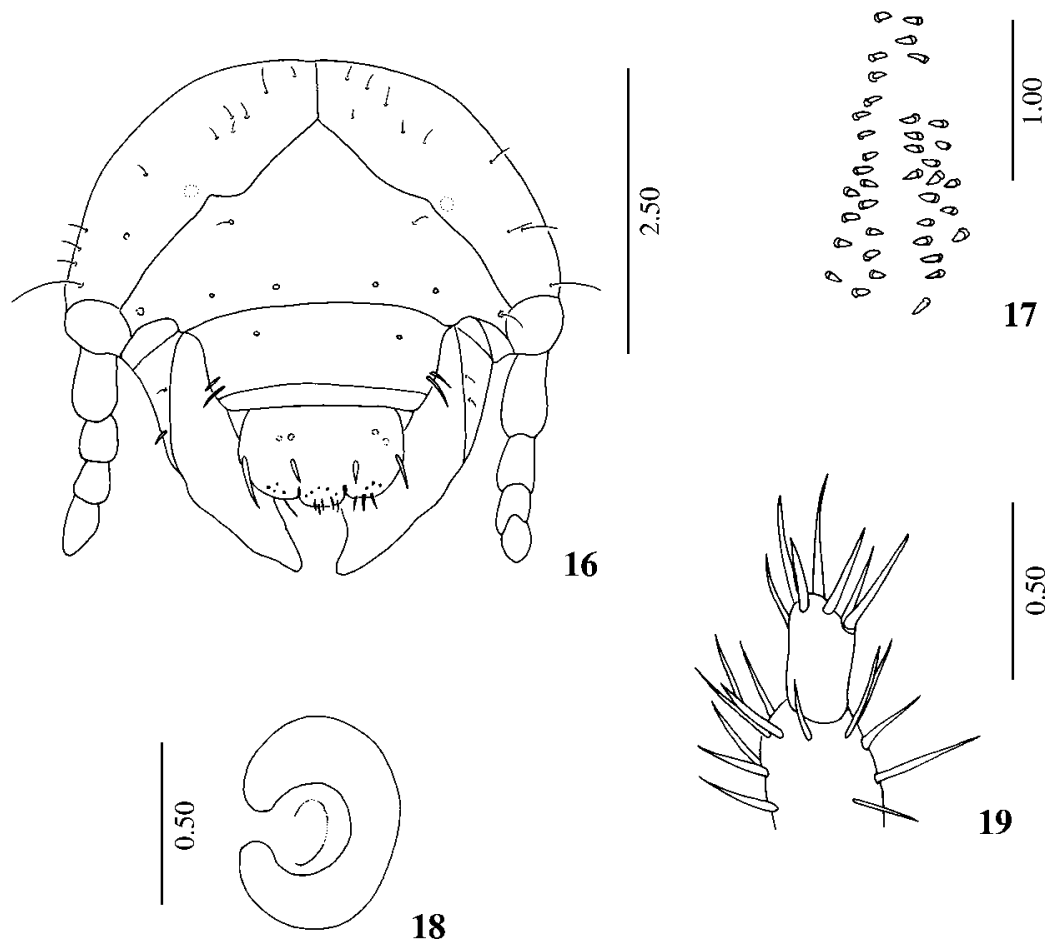

18

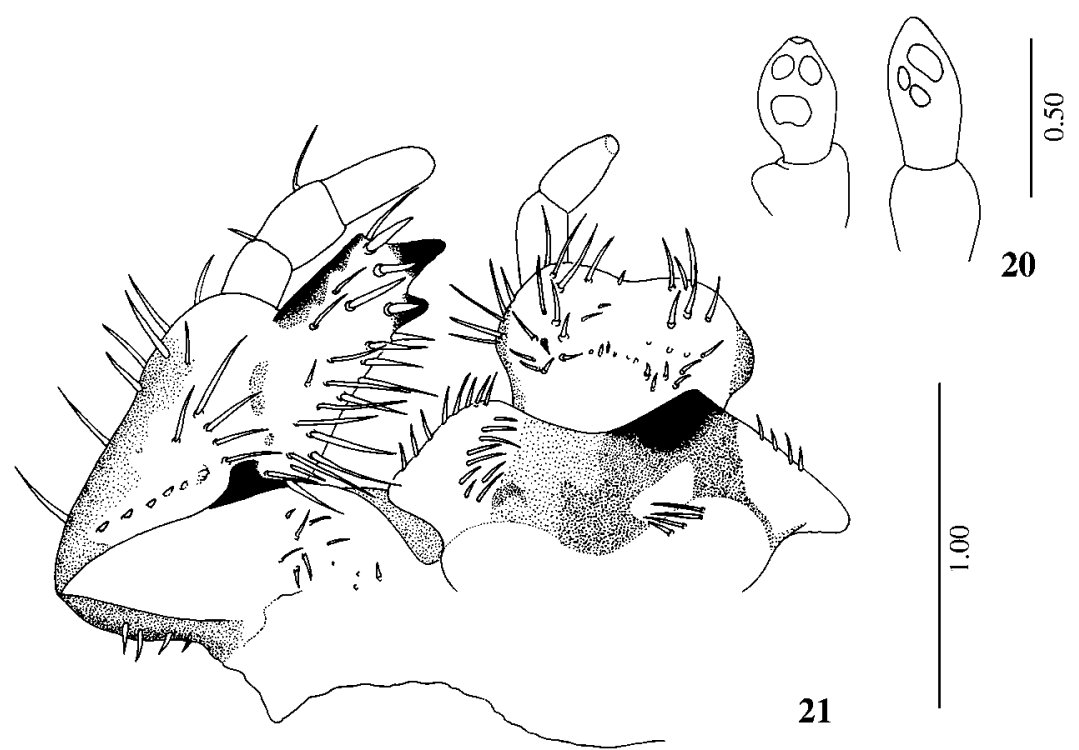

Figs. 16-21. Hologymnetis cinerea, third instar larva. 16) Frontal view of head; 17) Palidia; 18) Thoracic spiracle; 19) Tarsungulus of anterior leg; 20) Apical antennal segment, dorsal and ventral views; 21) Right maxilla, hypopharyngeal sclerome and labium, ventral view. 

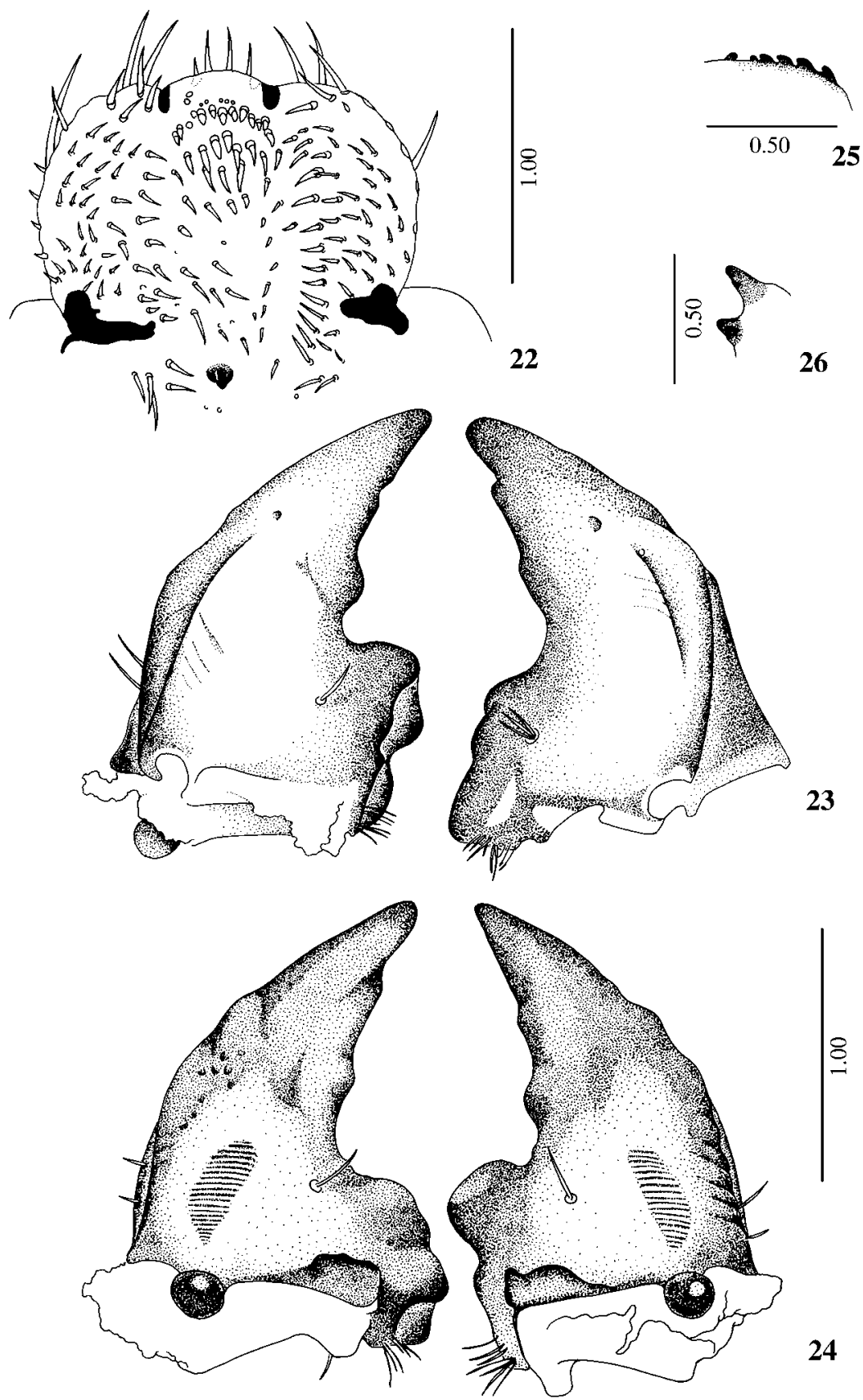

Figs. 22-26. Hologymnetis cinerea, third instar larva. 22) Epipharynx; 23) Dorsal view (a) left and (b) right mandibles; 24) Ventral view of (a) right and (b) left mandibles; 25) Stridulatory area of maxilla; 26) Apex of right mala showing unci. 
toparia with group of 57-60 setae on each side. Dexiotorma and pternotorma well developed. Laeotorma short, broad. Nesia with sensorial cone. Haptolachus with 3 sensillae below sensorial cone. Mandibles. Left mandible (Figs. 23a, 24b) with 1 scissorial tooth anterior to scissorial notch and 2 scissorial teeth posterior to notch. Stridulatory area elongate-oval, length over 3 times its width. Lateral edge with 2-4 setae. Dorsal surface in apical half with 1 seta. Molar area bilobed, dorsal surface with 1 dorsomolar seta. Basomedial angle with brustia possessing 7 setae. Right mandible (Figs. 23b, 24a) with 2 scissorial teeth, stridulatory area similar in shape to that of left mandible. Lateral edge with 2-4 setae. Dorsal surface in apical half with 1 seta. Molar area trilobed, dorsal surface with 3 dorsolmolar setae. Basomedial angle with brustia possessing 7-9 setae. Calyx present. Maxilla. Galea and lacinia fused (Fig. 21), forming mala. Mala with large uncus at apex (Fig. 26), 2 subterminal unci fused at base and unequal in size, dorsal surface with 2-3 indistinct rows of setae. Cardo (Fig. 21) with 4-5 setae. Stridulatory area (Fig. 25) possessing a row of 5 curved, blunt teeth plus a distal, truncate process. Labium. Hypopharyngeal sclerome with group of 9 setae on left side, 4 setae on right; both lateral lobes with 5-8 setae arranged in 2-3 rows. Glossa with transversal row of 11-13 setae at base, a group of 15-16 setae arranged in 2 or 3 rows, and a pair of sensilla on each side. Antennae. Surface (Fig. 20) with 3 dorsal and 3 ventral sensory spots on terminal segment. Segment I of antenna equal in length to segments II and III combined. Thorax. Respiratory plate of thoracic spiracles (Fig. 18) C- shaped, $0.73 \mathrm{~mm}$ high and $0.50 \mathrm{~mm}$ wide, plate with 30 holes across diameter at middle, holes small and circular. Abdomen. Spiracles of abdominal segments I-VI similar in size, segments VII and VIII slightly larger. Scutum of abdominal segments I-VIII usually with 4-5 rows of short setae, each 3rd-4th row possessing several long setae. Segments IX and X fused, predominantly covered with short setae and fewer long setae. Spiracular area of abdominal segments I-VIII with 40-50 short and medium sized setae, pleural lobes with 25-35 setae. Raster distichous (Fig. 17), possessing irregular rows of 18-20 pali. Septula elongate-oval, length nearly 4 times its width. Tegilla composed of numerous short and long setae. Lower anal lip possessing numerous short setae, fewer long setae. Legs. Tarsungulus (Fig. 19) cylindrical, rounded apically, possessing 7 setae.

\section{Acknowledgments}

We thank Peter Holm (University of Arizona) for the loan of the Hologymnetis larvae. Miguel Morón is gratefully acknowledged for his assistance in recognizing the Hologymnetis larvae during a larval workshop held at the University of Nebraska State Museum in August 1999. We thank Angie Fox (Scientific Illustrator, University of Nebraska State Museum) for her habitus drawing of the adult of Hoplopyga singularis and Mark Marcuson (former illustrator at the Museum) for his illustration of the adult of Hologymnetis cinerea. Appreciation is extended to Dr. A. Mesa (Universidad Estadual Paulista (UNESP) de Rio Claro, São Paulo, Brazil) for his help and hospitality during the visit of E. Micó to Brazil in 1996. Micó's stay at UNESP was funded by an Intercampus/España-America Latina 96 grant from the Agencia Española de Cooperación Internacional of the Spanish Ministry of Foreign Affairs. Micó's stay at the University of Nebraska in 1999 was supported, in part, by a grant from the Consellería de Educación y Ciencia (Generalitat Valenciana). We thank Mary Liz Jameson (University of Nebraska) and Ed- 
uardo Galante (University of Alicante) for reviewing the manuscript. This project was supported, in part, by an NSF/PEET grant (DEB 9712447) to Brett C. Ratcliffe and Mary Liz Jameson.

\section{References Cited}

Bruch, C. 1919. Metamorfosis de Cotinis semiopaca Moser (coleóptero lamelicornio). Physis 4:392-399.

Costa, C., S. A. Vanin, and S. A. Casari-Chen. 1988. Larvas de Coleoptera do Brasil. Museu de Zoologia, Universidade de São Paulo. 282 pp., 165 plates.

Luederwaldt, H. 1911. Quatro lamellicorneos termitophilos. Revista do Museu Paulista 8:405-413.

Monné, M. A. 1969. Descripción del último estadio larval de "Macraspis dichroa cribrata" Waterh., "Blaesia atra" Burm. y "Marmarina tigrina" (Gory and Perch.) (Coleoptera, Scarabaeidae). Revista Brasileira da Biologia 29:367-376.

Morón, M. A., and B. C. Ratcliffe. 1984. Description of the larva and pupa of Argyripa lansbergei (Sallé) with new distributional records for the genus and a key to the New World Gymnetini larvae (Coleoptera: Scarabaeidae: Cetoniinae). Proceedings of the Entomological Society of Washington 86:760-768.

Ratcliffe, B. C., and A. C. Deloya. 1992. The biogeography and phylogeny of Hologymnetis (Coleoptera: Scarabaeidae: Cetoniinae) with a revision of the genus. Coleopterists Bulletin 46:161-202.

Ritcher, P. O. 1966. White Grubs and Their Allies. A Study of North American Scarabaeoid Larvae. Oregon State University Press, Corvallis. 219 pp.

Vanin, S. A., and C. Costa. 1984. Larvae of Neotropical Coleoptera. IX. Scarabaeidae, Cetoniinae, Gymnetini. Revista Brasileira da Entomologia 28:329-335.

(Received 21 February 2000; accepted 12 June 2000) 